\title{
Digital Marketing: Drivers for the Development of the Russian Agricultural Sector
}

\author{
Borisova L.V.', Baranova I.V. ${ }^{*}$, Bruzhukova O.V. $^{2}$ \\ ${ }^{1}$ FSBEI of HE Don State Technical University, Rostov-on-Don, Russian Federation \\ ${ }^{2}$ FSBEI of HE All-Russian State University of Justice (Russian Legal Academy of the Ministry of Justice of Russia), \\ Rostov-on-Don, Russian Federation \\ *Corresponding author. Email: bariv@bk.ru;
}

\begin{abstract}
.
The article considers the modern development trends of digital marketing and the prospects for its use in modern agribusiness. The availability of digital technology for most enterprises provides an opportunity to collect information about markets and consumers. The article analyzes some of digital marketing techniques, the experience, scope, capabilities and prospects of implementation in the agricultural sector. The main tools of digital marketing and the current state of the factors affecting the development of online sales in the agribusiness are analyzed. The choice of tools should be based on changes in customer behavior. The ongoing transformations in purchasing preferences and in the way of life spent time on the Internet make digital marketing tools a prerequisite for more efficient operation of the enterprise. It was revealed that for effective work in the field of Internet communications it is necessary to rely on the study of the behavior of the target audience in the buying process. All this data will help to choose the right and suitable tools for Internet marketing, improve the digital economy as a whole.
\end{abstract}

Keywords: digital marketing, online marketing, digitalization, electronic commerce, agriculture, advertising, sales development, social networks

\section{INTRODUCTION}

This article discusses one of the important areas of modern business development in various fields of life, including agricultural - digital marketing. Digital marketing is a fairly new phenomenon that is constantly being researched, dynamically developed and improved. Online sales are relevant in many areas. Currently, information is transmitted electronically to anywhere in the world without using additional resources for transport and couriers.

Users of different ages in the modern world are increasingly spending money on the Internet. Therefore, it is here that it is relevant to look for future buyers of agricultural products. The time of ordinary advertising has passed, people are tired of it and not so trust, and Internet marketing allows notifying everyone around about your product [1].

In simple terms, Internet marketing refers to actions aimed at promoting goods and services on the Internet. The main goal of Internet marketing is to turn website visitors into buyers, which will result in an increase in the profit of the enterprise.

Unlike classical marketing, Internet marketing has advantages such as:

- interactivity - the ability to directly interact with potential customers, keep in touch, monitor the situation and take control of it;
- targeting - selection from the entire audience of users only those who are interested in buying and show ads only to this audience;

- web analytics - allows understanding what kind of actions attracted more visitors to the site, who later became buyers, and also turned out to be more effective. When using online marketing, product prices will be lower because there is no need for physical presence. The main elements of Internet marketing (Theory 4P) are:

Product - the thing that is sold through the Internet. The product competes not only with sites, but also with real stores;

Price - it is generally believed that due to cost savings, the price on the Internet is lower than in the store;

Promotion - events to promote a product or brand on the network. Promotion tools can be contextual advertising, email, viral marketing, interactive advertising, working with blogs, etc.;

Place - the point of sale, the place of interaction between the seller and the buyer (for example, site, social network, advertisement, etc.) [2].

The agricultural business is a very important area of activity for all people living on our planet. Everyone uses what agriculture has given us. Nevertheless, even now, during the rapid development of information technology and Internet marketing, not all agricultural producers understand the importance of informatization and active contact with consumers on the network. 


\section{METHODS}

Increasing sales in Internet marketing is built not only in attracting website visitors, but also in returning customers. Indeed, if visitors return to the site to buy again, they will bring profit to the business. All this should be taken into account when planning agricultural products or, in another way, an online strategy.

A strategy in Internet marketing involves a course of action to increase sales. But having such a strategy does not mean that, as if by magic, sales will automatically increase. For everything to work out, strategies need to be followed. The strategy scheme is proposed in Figure 1.

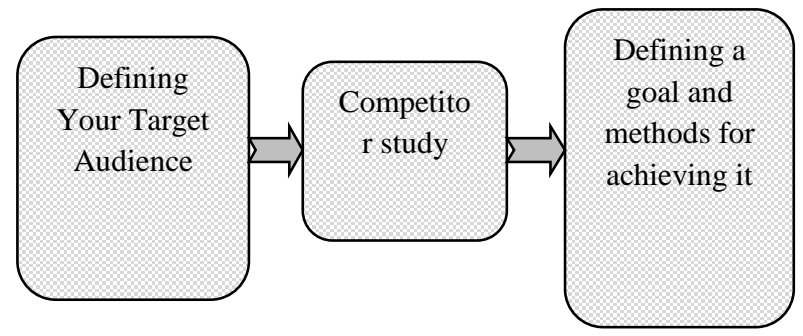

Figure 1 Internet Strategy

The first step is to identify your target audience. You need to understand why people buy your product, and make a portrait of the buyer.

The second step of this strategy is the need to study competitors and understand how best to satisfy the needs of your customers.

The third stage is the definition of goals and methods for achieving an online strategy.

Constantly required to conduct analysis and make adjustments to the strategy of action. Indeed, for Internet marketing there is no standard strategy that would work well for any business, especially for agrarian. And which of them will be effective can only be understood in practice. After all, the agro-industrial sector has a number of features: perishable goods, mismatch of the working period with the production period, a variety of forms of management, a variety of product mix.

The marketing activities of agricultural enterprises currently contribute to a more efficient management of the economy. This type of activity is focused not only on the regional consumer, but also on foreign economic activity. Working with social networks will allow the manufacturer to expand sales, communicate directly with consumers of these products. Conducting a dialogue on the blog will help to promote a positive attitude towards the product, which will strengthen the image of the enterprise $[5,6]$.

Results. According to studies of the All-Russian Center for the Study of Public Opinion, more than $80 \%$ of Russians use the Internet, and this further increases the importance of Internet technologies in the marketing activities of agroindustrial enterprises. And so that the impact on the consumer is as stimulating as possible for a purchase, a qualified specialist who is versed in the specifics of the work of the media should be involved in creating a group or advertising on the Internet. Among the most active audience, highly educated $-78 \%$ and materially well-off $72 \%$ who use the Internet daily stand out.

Therefore, it is necessary to more carefully and efficiently think through the presentation of online advertising on agricultural products. The technology of positioning, determining the place of goods in the minds of consumers, provides agricultural products with a competitive advantage in the market. This is usually used by large agribusinesses. They skillfully draw attention to the fact that their products are fresh and natural, and now it is very relevant for the consumer.

According to research by Avito and Data Insight, the ecommerce market between individuals has doubled in two years. The market for trade between individuals in monetary terms grew by $92 \%$ in two years (from 295 billion rubles in 2017 to 568 billion rubles in 2019). Another interesting point is that the number of sellers is growing faster than the number of buyers. Half of those who made sales on the Internet within six months made one or two sales during this period of time. There are more sellers among a young audience. The main age category of sellers is 25-34 years old. Almost the same distribution of sellers by gender in 2019 is observed - 53\% of men and $47 \%$ of women. And in general, the "average seller" is a family man aged 30+ with an average income. [7]

In the framework of this study, it was revealed that Internet marketing includes a marketing technology management system. The components of Internet marketing are identified through the definition of a communication operation. Communication operation involves an action related to the formation of demand and product promotion (presentation, advertising and press PR, conference, telemarketing, catalog marketing and electronic commerce through the Internet).

Changing the target audience provokes consideration of Internet marketing as part of processes that affect the information flow when achieving quantitative and cost characteristics. The information flow is divided into two types, characterizing changes in the target audience (Fig. 2). [8]

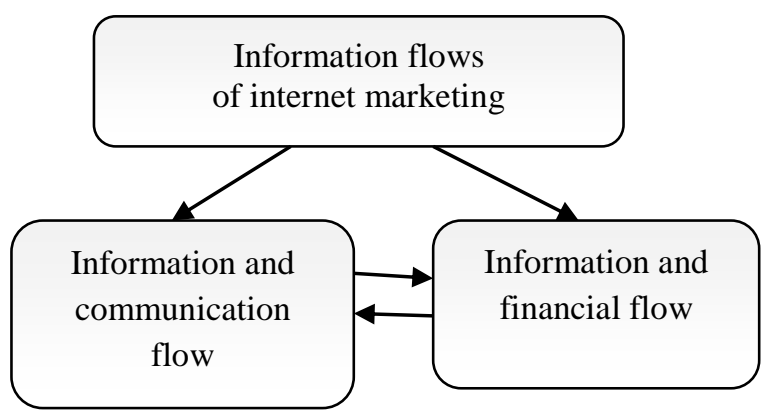

Figure 2 Classification of information flows of Internet marketing.

Tools for product promotion, including in the agricultural sector, are selected only when the target audience is determined, competitors are analyzed and goals are set. Among the main tools of Internet marketing are: 
1) Landing (landing pages) is a one-page site that presents a product or service. The main task is to press the "buy" or "register" button;

2) web analytics - collection and analysis of information about visitors and their actions in order to improve business processes on the site. Web analytics services are Google Analytics - www.google.ru/analytics and Yandex.Marketing - www.metrika.yandex.ru. Internet marketing and analytics are closely related and cannot exist separately from each other;

3) social networks - a convenient form of distribution of your goods (SMM). In a social network account, you can not only talk about a product or a company, but also communicate directly with your audience. Currently popular networks: Facebook (facebook.com), Vkontakte vk.com, Twitter (twitter.com), Instagram (instagram.com), YouTube (youtube.com).

When choosing a means to promote a product through the Internet, it is required to have an idea of the audience's readiness to purchase it. Conventionally, the target audience can be divided into "hot", "warm" and "cold".

"Hot" target audience - consciously looking for a specific product for its request, in order to meet its needs. Such buyers are only looking for suitable purchase conditions. Such an audience should be directed to the page of the site with goods that satisfy their needs.

"Warm" target audience - recognizes the need, but is not ready to find a solution in the current conditions. It can be directed to a page with useful information in order to push to satisfy a need.

"Cold" target audience - currently does not feel the need and may not have the resources to buy. Representatives of this group of buyers should be sent to a site with useful information where constant contact and counseling, social networks, and electronic letters are offered. Subsequently, such buyers will move into the category of "warm", there will be confidence in the product and push for a purchase. The following can be distinguished among the factors influencing the development of the companies' website: the level of computer literacy of the potential buyer, the level of solvency of the population, environmental conditions, and the state. Factors such as information technology, competitors' behavior, and search engines can also influence online purchases [9].

Currently, agricultural producers are faced with the issue of selling their products. This is especially acute in crop production, when large yields become almost a problem for implementation on the most favorable conditions. Each type of agricultural product has its own specifics, namely a short shelf life in certain conditions, especially transportation. All this should be taken into account when determining implementation methods and timelines. In this case, one should resort to the use of innovative technologies and the use of the latest methods to promote the manufactured products to the consumer, namely the use of the Internet.

Agricultural products can be sold over the Internet, especially crop products. For example, through electronic trading platforms, according to 44-FZ, public procurement is conducted through tenders. In Russia, electronic trading platforms of this kind are owned by Sberbank AST (sberbank-ast.ru), RTS tender - electronic trading platform (rts-tender.ru), MICEX - National Electronic Marketplace (etp-micex.ru), Roseltorg State Trading Platform (roseltorg .ru), Zakaz Electronic Trading Platform (Zakaz.ru), The Auction House of the Russian Federation (since 2016). Non-state online sales are also carried out according to 223-FZ.

There are sites such as rynok-apk.ru where ads are presented by categories (agricultural machinery, equipment, spare parts, animals, seeds, crop products, containers, services, etc.). The agro-industrial complex market is a board of free agricultural advertisements. On this site, people can easily place an advertisement for the sale of agricultural machinery or the purchase of livestock. In the Work section, those who wish can respond to offers on seasonal work in agriculture; in the News section information on the latest developments in the agroindustrial complex [3, 4].

On the Internet, people can also find information sites on fairs. This gives farmers the opportunity to sell fresh, highquality products of a new level without intermediaries, and it gives people the opportunity to buy fresh vegetables and fruits at affordable prices.

On agricultural trading platforms (trade.agroinform.asia) in the Internet space, people can find information about buyers and sellers on livestock products (meat of various types, feed, milk), legumes, vegetables, processed products, seeds, poultry farming, agricultural machinery, fertilizers, etc.

There are trading systems such as AGRORU.com, where people can find or buy agricultural products by region. Examples of marketplaces connecting farmers with the final consumer are:

- Electronic farmer - allows ordering products from farmers with delivery;

- Smart Seeds - for ordering and transporting agricultural products;

- Agro24 - for bulk purchases of products and agricultural goods with access to prices and transactions;

- PROD.CENTER - an agricultural trading platform for manufacturers and processors;

- AgroCargo - for transportation of products;

- FoodZa - connects restaurants with farmers;

- Agroserver; and Agrobaza - bulletin boards for the purchase or sale of machinery and equipment;

- Esh' derevenskoe (Eat country food) - allows small farmers to display their products on the site;

- Yorso - B2B - point of sale for large parties of seafood and fish;

- IDK - an electronic platform selling agricultural crops;

- MFlowers - B2B - a platform connecting flower buyers, manufacturers and logisticians around the world;

- TVOY PRODUCT - a platform connecting buyers and producers of agricultural products. 
and make appropriate adjustments, study representatives, and use business relationships.

Large agricultural enterprises need to use advertising that will rely on media, namely the Internet, because it is inexpensive and effective. It is also acceptable to create groups on social networks to promote their products, use blogs. In social networks, consumers can discuss the products of this manufacturer, and the manufacturer will be able to directly contact the target audience. And only in this case, the marketing management system in the agricultural sector will be economical, taking into account the agribusiness policy, consumer demand, competition and market conditions. The right approach and analysis of the available data will allow choosing the right digital marketing tools, thereby improving the digital economy as a whole.

\section{REFERENCES}

[1] O. Tolstyakova, O. Semenova, Model' upravleniya / Theoretical and practical issue of ensuring the economic interests of the modern innovativ society, B\&M Publishing, San Francisisco, California, USA, 2013, pp.170-173.

[2] L. Fudshchrova Kak s pomoshch'yu e-mailmarketinga sozdat' sistemu prodazh v internet-magazine // Internet-marketing. 1 (2018) 58-63.

[3] D. Khalilov Marketing $\mathrm{v}$ sotsial'nykh setyakh. Pervoye rukovodstvo po marketingu $\mathrm{v}$ sotssetyakh ot rossiyskogo praktika, Mann, Ivanov i Febber, 2013.

[4] A. Temichev, M. Akulich, Kontent-marketing kak instrument prodvizheniya $\mathrm{v}$ internete, Promyshlennyy marketing, 6 (2014) 68-71.

[5] I. Baranova, O.Bunchikov, R. Yeremin, Analiz razvitiya form kraudfandinga $\mathrm{V}$ finansirovanii sotsial'nykh proyektov, Uspekhi sovremennoy nauki, 11(3) (2016) 7-11

[6] D. Vlasenko, «Internet-marketing i sel'skoye khozyaystvo», Vserossiyskiy fermer internet zhurnal, 13.05.2019, [data obrashcheniya 19.11.2019] http://vfermer.ru/rubrics/economic/economic_369.html

[7] F. Virin, Issledovaniye Avito i Data Insight: rynok internet-torgovli mezhdu chastnymi litsami vyros za dva goda", https://www.shopolog.ru/metodichka/analytics/issledov anie-rynka-roznichnogo-onlayn-eksporta-v-rossii-2019/

[8] A.Ye. Kovalenko, I.Yu. Okol'nishnikova, V.M. Katochkov, Preobrazovaniye informatsionnykh potokov $\mathrm{v}$ internetmarketingovoy deyatel'nosti predpriyatiy 
malogo biznesa, Marketing MBA. Marketingovoye upravleniye predpriyatiyem 3 (2018) 21-42.

[9] T.V. Maksiyanova, Analiz faktorov, okazyvayushchikh vozdeystviye na funktsionirovaniye internet-kompaniy $\mathrm{v}$ sisteme internet-kommertsii // Gumanitarnyye i sotsial'no-ekonomicheskiye nauki. 6 (2011) 134-137.

[10]Y. Yorozu, M. Hirano, K. Oka, and Y. Tagawa, "Electron spectroscopy studies on magneto-optical media and plastic substrate interface," IEEE Transl. J. Magn. Japan, vol. 2, pp. 740-741, August 1987 [Digests 9th Annual Conf. Magnetics Japan, p. 301, 1982].

[11]M. Young, The Technical Writer's Handbook. Mill Valley, CA: University Science, 1989. 